\title{
Mitigasi Resiko Akad Pembiayaan Mudharabah pada Perbankan Syariah
}

\author{
Eka Jati Rahayu \\ Universitas Islam Negeri (UIN) Sunan Kalijaga Yogyakarta \\ ear_ef_ra@yahoo.co.id
}

\begin{abstract}
Abstrak:
Perbankan syariah mulai berkembang tahun 1970 dengan akad mudharabah (profit and loss sharing) sebagai ciri khasnya. Akad mudharabah dipercaya mampu mendorong produktivitas sektor rill dan menjadi solusi krisis ekonomi, karena dapat mengeliminasi unsur bunga. Namun dalam prakteknya perbankan syariah lebih banyak mengaplikasikan akad yang berbasis jual beli (murabahah) dalam berbagai taransaksinya. Hal ini dilatarbelakangi oleh besarya resiko yang ditanggung perbankan syariah jika mengaplikasikan akad mudharabah. Banyak resiko yang akan ditanggung dari akad mudharabah, namun bukan berarti akad mudharabah tidak bisa dikembangkan. Perbankan syariah dapat melakukan mitigasi resiko yang baik, sehingga akad mudharabah kembali diaplikasikan dengan baik. Adapun hasil penelitian yang ditemukan adalah resiko dalam akad mudharabah yaitu: Pertama, permasalahan agency. Kedua, permasalahan jaminan. Ketiga, peran investor dan manajemen. Keempat, efek diversifikasi waktu pada ekuitas. Kelima, manajemen asset. Perbankan syariah bisa menerapkan mitigasi resiko yaitu: Pertama, penetapan adalanya penjamin dan fix asset sebagai agunan. Kedua, menetapkan rasio maksimal biaya operasi terhadap pendapatan operasi. Ketiga, penerapan prinsip profit and loss sharing pada akad penyertaan modal dan reveue sharing pada akad penghimpunan dana.
\end{abstract}

Keywords: Mudharabah, mitigasi resiko, perbankan syariah. 


\begin{abstract}
:
Islamic banking began to develop in 1970 with a contract mudharabah (profit and loss sharing) as a trademark. Mudharabah contract believed to be able to push productivity rill sector and provide a solution to the global economic crisis due to eliminating elements of interest. But the more sharia banking practice applying transaction-based contract (Murabahah) in various transactions. This is largely grounded in sharia banking risks incurred when applying mudharabah contract. Although many of the risk to be obtained, but it does not mean mudharabah contract can not be developed. Islamic banking can do a good risk mitigation mudharabah contract back up properly applied. The result found is risk mudharabah contract, namely: First, agency problems. Second, the problems of security. Third, investors and the role's management. Fourth, time diversification effect on equities. Fifth, asset management. Islamic banking can apply risk mitigation, namely: First, the setting of the availability of surety and fix assets as collateral. Second, insist on maximal ratio of operational costs to operating income. Third, the principle of Profit and Loss on contract shariang capital participation and sharing in contract assembly reveue funds.
\end{abstract}

Keywords: mudharabah, risk mitigation, Islamic banking.

\title{
Pendahuluan
}

Islam sangat menganjurkan pemeluknya untuk berusaha, termasuk melakukan kegiatan-kegiatan bisnis. Dalam kegiatan bisnis, seseorang dapat merencanakan suatu dengan sebaik-baiknya agar dapat menghasilkan sesuatu yang diharapkan, namun tidak ada seorangpun yang dapat memastikan hasilnya seratus persen. Suatu usaha walaupun direncanakan dengan sebaik-baiknya namun tetap mempunyai resiko untuk gagal. Faktor ketidakpastian adalah faktor yang given yang sudah menjadi sunnatullah.

Konsep bagi hasil, dalam menghadapi ketidakpastian merupakan salah satu prinsip yang sangat mendasar dari ekonomi Islam, yang dianggap dapat mendukung aspek keadilan. Keadilan merupakan aspek mendasar dalam perekonomian Islam. Penetapan suatu hasil usaha didepan dalam suatu kegiatan 
usaha dianggap sebagai sesuatu hal yang dapat memberatkan salah satu pihak yang berusaha, sehingga melanggar aspek keadilan.

Bahwa kegiatan-kegiatan investasi bank Islam oleh para teoritisi Perbankan Islam membayangkan mesti di dasarkan pada dua konsep hukum: Mudharabah dan Musyarakah, atau yang dikenal dengan istilah Profit and Loss Sharing (PLS). Apakah konsep teoritis yang ditawarkan dengan sistem mudharabah dalam literatur fikih dapat diaplikasikan secara murni dalam tingkat realitas?

\section{Mudharabah dalam Perspektif Ekonomi Islam}

Masyarakat Hijjaz menyebut mudharabah dengan kata qiradh. Menurut bahasa qiradh diambil dari kata al-qardhu yang memiliki al-qath'u (potongan) sebab pemilik harta memberikan potongan hartanya kepada pengusaha untuk dikelola (Sabiq, 1995: 154). Dari hasil usaha itu, pengusaha memberikan potongan keuntungannya kepada pemilik. Mudharabah juga bisa diambil dari kata muqaradah yang berarti al musawah (kesamaan) sebab pemilik modal dan pengusaha memiliki hak yang sama terhadap terhadap keuntungan. Berbeda dengan masyarakat Hijjaj, para ulama Iraq menyebut dengan ungkapan mudharabah, sebab setiap orang yang melakukan akad memiliki bagian dari laba (Syafe'i, 2004: 223).

Mudharabah berasal dari kata dharb yang berarti memukul atau berjalan. Pengertian memukul atau berjalan lebih mengarak kepada proses seseorang memukulkan kakinya dalam menjalankan sesuatu (Qal'aji, 1985). Dalam tataran teknis mudharabah merupakan akad kerjasama usaha antara dua pihak di mana pihak shahibul maal menyediakan seluruh modal, sedangkan pihak lainnya sebagai pengelola. Keuntungan dari usaha dibagi menurut kesepakatan yang di tuangkan dalam kontrak, sedangkan apabila mengalami kerugian maka ditanggung oleh pemilik modal selama kerugian itu bukan akibat kelalaian pengelola. Apabila kerugian diakibatkan oleh kelalaian pengelola maka pengelola harus bertanggung jawab atas kerugian tersebut (Antonio, 2009: 95).

Mudharabah adalah jenis khusus kemitraan di mana salah satu pasangan memberikan uang kepada orang lain untuk berinvestasi di perusahaan komersial. Investasi berasal dari mitra pertama yang disebut rabb al-mal, sementara pengelolaan dan bekerja adalah tanggung jawab eksklusif yang lain, yang disebut mudharib. Mudharabah juga merupakan pernyataan yang mengan- 
dung pengertian bahwa seseorang memberi modal niaga kepada orang lain agar modal itu diniagakan di mana perjanjian keuntungannya dibagi antara dua belah pihak sesuai perjanjian, sedang kerugian ditanggung oleh pemilik modal.

Filosofi dasar dari mudharabah adalah untuk menyatukan capital dengan labour (skill dan enterpreneur) yang selama ini senantiasa terpisah dalam sistem konvensional. Dalam mudharabah akan tampak jelas sifat dan semangat kebersamaan dan keadilan, Hal ini terbukti melalui kebersamaan dalam menanggung resiko kerugian yang dialami proyek dan membagikan keuntungan pada waktu ekonomi sedang booming.

Adapun landasan syariah dari mudharabah adalah Al-Qur'an, hadis dan ijma'. Dalam Al-Qur'an surat al-Muzzammil: 20 disebutkan sebagai berikut:

$$
\text { واخرون يضربون في الارض يبتغون من فضل الله ...(المزمل :20) }
$$

Artinya :

"Dan dari orang-orang yang berjalan di muka bumi mencari sebagian karunia Allah SWT." (QS. Al-Muzzammil: 20)

Argumentasi (وجه الدلاله) dari ayat di atas adalah "orang-orang yang berjalan di muka bumi" diinterpretasikan sebagai orang-orang yang melakukan suatu perjalanan usaha.

Dalam firman Allah lainnya disebutkan sebagai berikut:

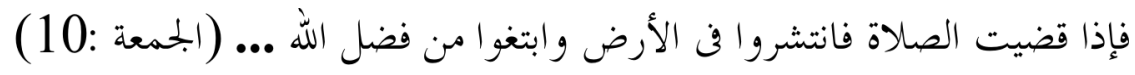

Artinya :

"Apabila telah ditunaikan shalat maka bertebaranlah kamu di muka bumi dan carilah karunia Allah SWT.” (QS. Al-Jumu'ah: 10)

Sedangkan dalil yang menjelaskan tentang mudharabah dalam hadis disebutkan sebagai berikut:

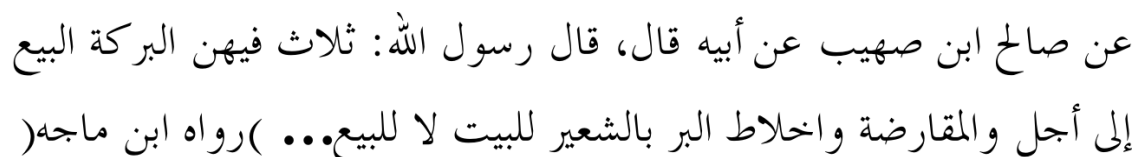

Artinya : 
"Dari Shalih bin Suhaib RA bahwa Rasulullah bersabda: tiga hal yang di dalamnya terdapat kebaikan: jual-beli secara tangguh, muqaradhah (mudharabah), dan mencampur gandum dengan gandum untuk keperluan rumah bukan untuk dijual." (Ibnu Majah)

Adapun dalil dari ijma' adalah fakta bahwa para sahabat telah berkonsensus terhadap legitimasi pengolahan harta yatim secara mudharabah. Kesepakatan para sahabat ini sejalan dengan spirit hadist yang dikutip Abu Ubaid (Antonio, 2009: 97).

Secara umum, mudharabah terbagi menjadi dua jenis: mudharabah muthalaqah dan mudharabah muqayyadah (Saeed, 2006: 79). Mudharabah muthlaqah adalah bentuk kerja sama antara shahibul maal dan mudharib yang cakupannya sangat luas dan tidak dibatasi oleh spesikasi jenis usaha, waktu dan daerah bisnis. Dalam pembahasan fikih, ulama seringkali mencontohkan dengan ungkapan if 'al ma syi ta (lakukanlah sesukamu) dari shahibulmaal ke mudharib yang memberi kekuasaan sangat besar (Antonio, 2009: 97).

Sedangkan mudharabah muqayyadah atau disebut juga dengan istilah restricted mudharabah/specified mudharabah adalah kebalikan dari mudharabah muthlaqah, si mudharib dibatasi dengan batasan jenis usaha,waktu, atau tempat usaha. Adanya pembatasan ini seringkali mencerminkan kecenderungan umum si Shahibul-maal dalam memasuki jenis usaha (Sudarsono, 2007:66-67).

\section{Pelaksanaan Teknis Akad Mudharabah}

Secara teknis, mudharabah adalah akad kerja sama usaha antara dua pihak, di mana pihak pertama (shahibul mal) menyediakan modal sedangkan pihak lainnya menjadi pengelola. Karena sifatnya itulah mudharabah lebih praktis untuk dijalankan pada perbankan Islam dibandingkan dengan syirkah (Sudarsono, 2007: 66-67).

Dari sisi modal, untuk menghindari segala macam perselisihan kontrak mudharabah harus merinci dengan jelas jumlah modalnya. Modal tidak boleh dalam satuan hutang yang dipinjam mudharib pada saat dilangsungkannya kontrak mudharabah. Tidak satupun dari madzhab sunni mengizinkan satu kontrak di mana kreditur meminta debitur untuk menjalankan mudharabah dari hutang. Dalam kontrak semacam ini investor dapat dengan mudah menggunakan 
mudharabah sebagai alat untuk memperoleh kembali hutangnya dengan mengambil keuntugan. Menurut Ibn Rusyd dan Malik alasan tidak mengizinkan alur seperti itu dikarenakan khawatir kalau hal itu menjurus kepada riba yang di praktikan pada masa pra Islam (Saeed, 2006: 78).

Aplikasi Mudharabah pada Perbankan Syariah dapat berbentuk penghimpunan dana maupun pembiayaan. Pada sisi penghimpunan dana (funding), mudharabah dipergunakan untuk: a) tabungan berjangka, dimaksudkan untuk tujuan umum, yang dapat dipakai untuk usaha apa saja yang tidak melanggar syariat, misalnya deposito biasa; b) Deposito spesial, di mana dana yang dititipkan nasabah khusus untuk usaha tertentu saja. Adapun dari sisi pembiayaan (financing), mudharabah dipergunakan untuk: a) pembiayaan modal kerja, seperti modal kerja untuk perdagangan, industri atau jasa; b) Investasi khusus, maksudnya sumber dananya khusus dan penyalurannya juga khusus, dengan syarat-syarat yang telah ditetapkan oleh shahibul mal.

Banyak manfaat yang dapat diambil dari mudharabah yang selama ini telah diterapkan di perbankan syariah, karena mudharabah memiliki karakter-karakter yang lebih adil. Di antaranya adalah: 1) Bank akan menikmati peningkatan hasil pada saat keuntungan usaha nasabah meningkat; 2) Bank tidak berkewajiban membayar bagi hasil kepada nasabah pendanaan secara tetap, tetapi disesuaikan dengan pendapatan/hasil usaha bank sehingga bank tidak mengalami negative spread; 3) Pengembalian pokok pembiayaan disesuaikan dengan cash flow sehingga tidak memberatkan nasabah; 4) Bank akan lebih selektif dan hati-hati mencari usaha yang bukan hanya sesuai dengan syariah, namun juga mempunyai prospek yang baik (Muhammad, 2002: 109-129).

\section{Problematika dalam Mudharabah}

Dalam literatur ekonomi Islam dan perbankan syariah yang dipublikasikan dalam rentang waktu antara 1960-an hingga 1970-an, dijelaskan bahwa bankbank syariah itu berfungsi sebagai lembaga keuangan, di mana keseluruhan pinjaman bisnis yang diberlakukan kepada pengusaha (nasabah) berdasarkan prinsip bagi hasil (profit and loss sharing) (Saeed, 2003: 124-125). Hal ini juga yang terjadi di tanah air. Kondisi ini sebenarnya menurut Adiwarman Karim adalah dalam rangka membedakan antara bank syariah dan bank konvensional 
yang beroperasi dengan sistem bunga. Meskipun demikian. Bank-bank Islam sejauh ini menggunakan sistem bagi hasil, namun secara praktik lebih banyak menggunakan metode pembiayaan lainnya seperti jual beli, leasing, dan lain sebagainya (Karim, 2003: 175).

Bagi hasil seharusnya merupakan mekanisme yang dominan di bank syariah. Namun kenyataannya, mekanisme produk bagi hasil tidak menunjukan prosentase yang cukup tinggi. Walaupun mudharabah dikatakan sebagai sesuatu yang ideal untuk perbankan Islam, dan "lebih baik" dibandingkan dengan sistem lainnya, namun ternyata mudharabah dalam kenyataaannya belum menjadi skema pembiayaan yang utama pada bank syariah. Berdasarkan data dari Bank Indonesia yang disampaikan melalui laporan Statistik Perbankan Syariah diperoleh data sebagai berikut :

Tabel 1

Jumlah Kantor Perbankan Syariah

\begin{tabular}{|l|c|c|c|}
\hline BUS & $\mathbf{2 0 1 0}$ & $\mathbf{2 0 1 1}$ & $\mathbf{2 0 1 2}$ \\
\hline Jumlah Bank & 11 & 11 & 11 \\
\hline Jumlah Kantor & 1215 & 1401 & 1686 \\
\hline \multicolumn{5}{|l|}{} \\
\hline UUS & $\mathbf{2 0 1 0}$ & $\mathbf{2 0 1 1}$ & $\mathbf{2 0 1 2}$ \\
\hline Jumlah Bank & 23 & 24 & 24 \\
\hline Jumlah Kantor & 262 & 336 & 502 \\
\hline \multicolumn{5}{|l}{} \\
\hline BPRS & $\mathbf{2 0 1 0}$ & $\mathbf{2 0 1 1}$ & $\mathbf{2 0 1 2}$ \\
\hline Jumlah Bank & 150 & 155 & 156 \\
\hline Jumlah Kantor & 286 & 364 & 368 \\
\hline
\end{tabular}

(Bank Indonesia, 2012: 1) 


\section{Tabel 2}

Komposisi Dana Pihak Ketiga dalam Milyar Rupiah

\begin{tabular}{|l|l|l|l|l|l|l|}
\hline \multirow{2}{*}{ Produk } & \multicolumn{4}{l}{ BUS \& UUS } & \multicolumn{2}{l|}{ BPRS } \\
\cline { 2 - 7 } & $\mathbf{2 0 1 0}$ & $\mathbf{2 0 1 1}$ & $\mathbf{2 0 1 2}$ & $\mathbf{2 0 1 0}$ & $\mathbf{2 0 1 1}$ & $\mathbf{2 0 1 2}$ \\
\hline Giro Wadiah & 9,056 & 12,006 & 15,094 & 0 & 0 & 0 \\
\hline Tabungan Wadiah & 3,338 & 5,394 & 7,035 & 285,066 & 412,034 & 498,870 \\
\hline Tabungan Mudharabah & 19,570 & 27,208 & 33,819 & 373,693 & 447,810 & 534,079 \\
\hline Deposito Mudharabah & 44,072 & 70,806 & 78,504 & 945,020 & $1,235,490$ & $1,742,580$ \\
\hline
\end{tabular}

(Bank Indonesia, 2012: 14)

Tabel 3

Komposisi Pembiayaan dalam Milyar Rupiah

\begin{tabular}{|l|l|l|l|l|l|l|}
\hline \multirow{2}{*}{ Produk } & \multicolumn{3}{c|}{ BUS \& UUS } & \multicolumn{3}{c|}{ BPRS } \\
\cline { 2 - 7 } & \multicolumn{1}{|c|}{$\mathbf{2 0 1 0}$} & $\mathbf{2 0 1 1}$ & $\mathbf{2 0 1 2}$ & \multicolumn{1}{c|}{$\mathbf{2 0 1 0}$} & \multicolumn{1}{c|}{$\mathbf{2 0 1 1}$} & \multicolumn{1}{c|}{$\mathbf{2 0 1 2}$} \\
\hline Mudharabah & 8,631 & 10,229 & 11,438 & 65,471 & 73,856 & 94,929 \\
\hline Musyarakah & 14,624 & 18,960 & 25,207 & 217,954 & 238,496 & 320,615 \\
\hline Murabahah & 37,508 & 56,365 & 80,953 & $1,621,526$ & $2,206,455$ & $2,784,644$ \\
\hline Salam & 0 & 0 & 0 & 45 & 20 & 348 \\
\hline Istisna & 347 & 326 & 355 & 27,598 & 23,673 & 21,458 \\
\hline Ijarah & 2,341 & 3,839 & 6,434 & 13,499 & 13,815 & 9,864 \\
\hline Qardh & 4,731 & 12,937 & 11,195 & 63,000 & 72,095 & 80,040 \\
\hline
\end{tabular}

(Bank Indonesia, 2012: 14)

Beberapa problematika penyebab mudharabah menjadi kurang berkembang, antara lain sebagai berikut:

Pertama, kontrak profit loss sharing dikaitkan dengan agency problems, manakala seorang pengusaha tidak mempunyai insentif untuk memberikan usaha tetapi mempunyai insentif untuk melaporkan profit yang lebih rendah dibandingkan dengan pembiayaan pribadi dari manajer. Argumen ini berdasar- 
kan ide bahwa pihak-pihak pada transaksi bisnis akan melalaikan, jika mereka dikompensasi kurang dari kontribusi marginal pada proses produksi. Manakala ini terjadi pada kasus profit loss sharing, kaum kapitalis ragu-ragu untuk berinvestasi berdasarkan basis profit loss sharing. Sebagai contoh A meminjam uang pada bank syariah $\mathrm{B}$, kemudian ia melaporkan keuntungannya pada laporan laba rugi dengan nilai usaha yang lebih rendah. Sehingga, tingkat profitloss sharing yang diberikan kepada bank lebih rendah.

Kedua, kontrak profit loss sharing membutuhkan jaminan agar dapat berfungsi secara efisien. Sedikitnya jaminan hak property pada kontrak profit loss sharing menyebabkan kegagalan praktik, karena tidak ada aturan tentang jaminan yang melandasinya. Pada praktiknya di Indonesia, jaminan hak property atas profit-loss sharing belum diatur dengan tegas dan jelas.

Ketiga, perbankan Islam menawarkan risiko yang lebih kecil dari pembiayaan dibandingkan dengan perbankan konvensional. Hal ini berdasarkan konsep mudharabah dan musyarakah yang dianutnya. Tetapi seringkali pelaksanaannya manajemen asset dari mudharabah dan musharakah tidak sesuai ketentuan yang berlaku. Idealnya dana pada perbankan syariah disalurkan melalui kegiatan investasi pada asset riil. Tetapi pada kenyataannya di Indonesia, pengelolaan asset pada perbankan syariah masih terpusat pada Sertifikat Wadiah Bank Indonesia.

Keempat, batasan peran investor pada manajemen dan dikotomi struktur keuangan dari kontrak profit loss sharing menimbulkan ketidak partisipasian. Mereka tidak berbagi kontrak berdasarkan partisipasi pengambilan keputusan. Disatu sisi terlihat hanya pihak manajemen yang mengelola dana sedangkan investor hanya menikmati hasilnya.

Kelima, pembiayaan ekuitas tidak tepat bagi pembiayaan proyek jangka pendek manakala dihadapkan pada tingkat risiko yang tinggi (efek diversifikasi waktu pada ekuitas). Pada kasus di Indonesia, di mana banyak pengelolaan dana perbankan syariah yang disalurkan melalui Sertifikat Wadiah bank Indonesia, menimbulkan risiko yang tinggi jika pembiayaan tersebut berjangka pendek dan lebih berisiko lagi jika bank syariah menyalurkan pengelolaan dana melalui Jakarta Islamic Index. 


\section{Pengendalian Resiko akad Mudharabah}

Untuk mengurangi kemungkinan terjadinya resiko-resiko di atas, maka bank syariah menurut Adiwarman Karim dapat menerapkan sejumlah batasan-batasan tertentu ketika menyalurkan pembiayaan kepada mudharib (Karim, 2003: 186190), yang tujuannya agar mudharib secara sistematis "dipaksa" untuk berperilaku memaksimalkan keuntungan bagi kedua belah pihak baik mudharib itu sendiri maupun bagi shahibu al-mal. Batasan-batasan itu antara lain:

\section{Penetapan Agunan berupa Fixed Asset dan (atau) Adanya Lembaga Penjamin}

Penerapan jaminan juga akan mencegah mudharib melakukan penyelewengan karena jaminannya yang sudah diberikannya. Menurut Chapra untuk mengurangi resiko skema mudharabah, perlu adanya a loan guarantee scheme underwritten partly by the ghoverment and partly by the commercial banks. Demikian pula pendapat Chudhory, bahwa untuk menghubungkan sektor riil dengan sektor keuangan melalui pembiayaan mudharabah perlu adanya lembaga penjamin. Keberadaan lembaga ini sangat menentukan kemampuan bank syariah dalam menggerakan sektor riil melalui alokasi pembiayaan UKM dan dengan skim mudharabah. Lembaga ini yang akan melakukan investigasi mengenai perilaku mitera sehingga dapat dipercaya akan amanah dalam mengelola dana dan memiliki kemampuan dalam berusaha.

Bila amanahnya diragukan dan kemampuannya rendah tidak akan dijamin dalam memperoleh pembiayaan dari bank syariah. Untuk nasabah yang masih rendah kemampuannya lembaga dapat memberikan pelatihan sehingga nasabah yang memenuhi syarat (eligible) untuk memperoleh pembiayaan dari bank syariah dan dijamin oleh lembaga tersebut. Bank syariah akan memperoleh kembali dananya bila terjadi kegagalan nasabah karena negligence ataupun moral failure, namun bila kegagalan karena normal business loss, maka bank turut menanggung kerugian tersebut. Sistem jaminan ini sebenarnya telah dipraktekan pada bank-bank syariah di beberapa negara.

International Islamic Bank for Invesment and Development (IIBID) dalam menjalankan pembiayaan kontrak mudharabah menerapkan persyaratan adanya jaminan dari pihak mudharib untuk diberilan kepada bank. Salah satu persyaratan kontak mudharabah di Faisal Islamic Bank of Mesir (FIBE) adalah jika 
terbukti mudharabah tidak memanfaatkan dana atau tidak menjaga barang dagangannya sebagaimana mestinya, berdasarkan ketentuan persyaratan dari investor, di mana mudharib mengalami kerugian, maka jaminan (garansi) yang diberikan dijadikan sebagai ganti atas kerugian yang dialaminya. Dalam kasus tersebut, mudharib bertanggung jawab atas kerugian yang terjadi. Oleh karenanya jaminan yang disyaratkan dalam kontrak menjadi konpensasi pihak bank. Jika jaminan tidak cukup, maka mudharib harus memberikan tambahan jaminan dalam jangka waktu yang di tentukan (Saeed, 2003: 103).

Dalam kacamata fiqh mudharabah berlangsung berdasarkan amanah dan wakalah maka mudarib menjadi seorang amin (terpercaya) bagi shahibu almal yang berakad dengannya. Sementara itu modal yang ditangannya adalah merupakan amanah, karena itu menerima dan mengelolanya dengan seijin shaibu al- mal. Dengan demikian mudharib tidak menanggung resiko yang menimpa harta tersebut kecuali pada kasus penyelewengan, keteledoran dan unsure kesengajaan yang dilakukan mudharib (Zuhayli,1998: 159; lihat juga dalam alHaytami, 1998: 492-493).

Demikian pula mudharib menjadi wakil dari shahibu al-mal ketika mengelolanya dengan mengembangkannnya dalam perniagaan, karena pengelolaannya dengan shahibu almal maka hal itu merupakan realisasi dari arti wakalah dan amanah. Oleh karena itu jika shahibul maal menuntut adanya persyaratan jaminan (garansi) beserta ketentuan ketentuannnya kepada pengelola (mudharib), menurut pendapat Imam Malik dan Imam Syafi'i kontrak tersebut tidak sah. Dengan demikian dalam mudharabah prinsipnya tidak perlu mensyaratkan agunan sebagai jaminan, karena menurut ulama Hanifah dan Hanabilah walaupun mudharabah-nya dibenarkan tapi syaratnya batil (Ibn Rusyd, tth: 179; dan lihat Wahbah al-Zuhayli, 1997: 3945).

Namun pada kondisi zaman tertentu karena semakin tipisnya kekuatan iman dan amanah, banyak kasus penyelewengan dan penipuan (baik secara kwalitas maupun kwantitas), dan dengan menganut prinsip tidak boleh saling membahayakan sebagaimana tertera dalam kaedah fiqh yang diambil dari teks hadis Nabi SAW yang artinya: Dari Ibn Abbas ra, bahwa Rasulullah berkata: "Tidak boleh membahayakan orang lain dan tidak boleh membalas tindakan orang lain yang membahanyakan dengan bahaya pula". (HR. Ahmad dan Ibn Majah) (al-Shan'ani, 1990: 178) 
Oleh karenanya dalam kasus mudharabah dewasa ini kadang dibutuhkan sesuatu sebagai jaminan bagi shahibu al-mal yang diambil dari amil untuk keamanan modal shahibu al-mal. Dengan pertimbangan hal ini maka dibolehkan bagi shahibu al-mal untuk meminta agunan dari mudharib sebagai jaminan yang telah menjadi suatu kebutuhan (hajah) bagi kontrak syarikat mudharabah. Tetapi jaminan itupun sebenarnya harus fleksible, mudah dan tidak menyulitkan bagi mudharib. Maksudnya adalah jaminan tersebut dapat berbentuk moril yaitu: surat rekomendasi (tazkiyah) dari seseorang atau lembaga yang dapat dijadikan penjamain, terpercaya dan bertanggung jawab sebagaiaman dalam bentuk materil yaitu barang. Kedua bentuk jamiana inilah yang dapat dijadikan pemecah pada saat timbul masalah yang tidak diinginkan dari mudharib dengan cara yang adil, arif dan bijaksana. Kebolehan bagi shahibu al-mal untuk meminta suatu jaminan dari amil dapat berpijak pada kaedah usul fiqh yaitu "al-maslahah al-mursalah" (Khallaf, 1993: 126-133) yang mengacu kepada kebutuhan, kepentingan, kebaikan dan maslahah umum selama tidak bertentangan dengan prinsip dan dalil tegas syari' dan benar-benar membawa kepada kebaikan bersama yang tidak berdampak menyulitkan serta merugikan orang atau pihak lain secara umum.

\section{Penetapan Rasio Maksimal Biaya Operasi terhadap Pendapatan Operasi.}

Hal ini dimaksudkan agar mudharib menjalankan oprasi bisnisnya secara efisien. Bila rasio ini mencapai $100 \%$, berarti bisnis mudharib tidak menghasilkan keuntungan oprasional. Keadaan ini tentunya tidak menarik pemilik modal untuk investasi karena tidak ada yang dibagi hasilkan. Bila rasio ini mencapai $80 \%$, berarti ada marjin keuntungan oprasional sebesar $20 \%$, keuntungan inilah yang dapat dibagikan kepada pemilik modal. Untuk memastikan agat mudharib menjalankan bisnis mudarabahnya dengan efisien, maka dapat ditetapkan syarat agar mudharib harus selalu menjaga rasio ini maksimal misalnya $80 \%$. Dengan tetap berpegang pada komitmen untuk menerapkan prinsip profit and loss sharing pada akad mudharabah, maka perbankan syariah sebenarnya sudah bisa memulainya sekarang pada waktu berperan sebagai shahibu al-mal.

Moral hazard yang dikhawatirkan melekat pada nasabah penerima pembiayaan mudharabah sebenarnya bisa dikurangi dengan menyepakati terlebih dahulu biaya-biaya apa saja yang lazimnya ada pada suatu usaha tertentu yang 
dikelola mudharib. Pada akad pertama kemungkinan ada biaya penting yang luput dicantumkan dalam kesepakatan, namun pada akad-akad berikutnya biaya-biaya yang luput akan semakin berkurang. Memang di sini diperlukan proses belajar yang mungkin saja tidak terlalu lama sehingga akhirnya diketemukan standar biaya yang berlaku untuk suatu usaha tertentu dan demikian juga untuk usaha-usaha tertentu lainnya. Para ulama telah sepakat membolehkan dan mengakui syarat syarat atau ketentuan yang ditetapkan shaibu al-mal dalam menggunakan modal mudharabah dan mewajibkan kepada amil untuk menepatinya selama bermanfaat bagi kepentingan syarikat dan tidak bertentangan dengan kaidah dan hukum syariat.

Dalam sebuah hadis riwayat Thabrani menyatakan yang artinya Abbas bin Abdul Mutalib jika menyerahkan harta sebagi mudharabah, ia mensyaratkan kepada mudharibnya agar tidak mengarungi lautan dan tidak menuruni lembah, serta tidak membeli hewan ternak, jika persyaratan itu dilanggar, ia (mudharib) harus menanggung resikonya. Ketika persyaratan yang ditetapkan Abbas itu didengar Rasulullah, beliau membenarkannya. (HR. Thabrani dan Ibnu Abbas) (al-Baihaqi, th: 111).

Dan hadis Nabi yang artinya dari Amru ibn Auf al- Muzani ra, bahwasanya Rasulullah bersabda: "orang-orang muslim terikat dengan syarat-syarat antara mereka kecuali syarat yang menghalalkan yang haram atau mengharamkan yang halal." (HR.Tarmidzi) (al-Shan'ani, 1990: 178).

Dalam kitab-kitab fiqh disebutkan bahwa ada dua hak pengelola (mudharib) yaitu memperoleh biaya oprasional (al-nafaqah) dan keuntungan (al-ribh) (Zuhayli,1998: 3957). Dalam masalah biaya oprasional untuk mudharib, para ulama berbeda pendapat menurut Wahbah Zuhayli ada tiga pendapat tentang nafaqah untuk mudharib. Pertama, bagi Imam Syafi'i tidak boleh ada biaya bagi mudharib yang diambil dari harta mudharabah baik usaha mudharabah itu menetap ataupun berpergian kecuali ada ijin dari pemilik modal (shahibu al-mal) karena hak mudharib hanya dapat diambil dari keuntungan. Jika disyaratkan ada nafaqah bagi mudharib maka akad mudharabah tersebut tidak berlaku. Kedua, menurut Ibrahim an-Nakha' dan al-Hasan al-Basyri bahwa mudharib berhak nafaqah baik menetap maupun berpergian dalam usaha mudharabnya. Ketiga, pendapat jumhur ulama di antaranya Abu Hanifah, Malik dan Zaidiyah menyatakan bahwa Bagi mudharib biaya oprasional hanya untuk usaha mudharabah 
yang berpergian dan tidak bagi yang menetap. Menurut golongan Hambali dibolehkan mudharib menyaratkan adanya biaya oprasional (nafaqah) baginya baik dalam keadan menetap ataupun mengadakan perjalanan dalam usahanya (Zuhayli,1998: 3957).

Sedangkan standar biaya oprasional menurut Ulama Hanafiyah adalah sesuatu yang lazim memenuhi kebutuhan hidup seperti makanan, biaya administrasi, transportasi dan lain-lain dan yang paling penting penetuan standar jumlah biaya oprasional menurut Abu Hanifah adalah standar biaya yang lazim telah diketahui oleh pelaku bisnis dan tidak berlebih-lebihan. Apabila mudharib melanggar dengan menggunakan biaya oprasional lebih dari kelaziman usaha maka ia harus menanggung (Zuhayli,1998: 3957).

Dengan demikian usaha bisnis dengan sistem bagi hasil ini secara langsung membangun etika bisnis yang transparan, jujur, amanah dan berkeadilan. Untuk mendukung agar sekema bagi hasil ini lebih menarik di perbankan syariah, maka lembaga yang berwenang seyogyanya menetapkan standar baku biaya oprasional pada tiap jenis usaha.

\section{Kembali kepada Asas Profit Loss Sharing pada Akad Penyertaan Modal dan Revenue Sharing pada Akad Penghimpunan Dana.}

Permasalahan pilihan profit and loss sharing atau revenue sharing sebenarnya permasalahan yang khas pada akad penyertaan modal di perbankan syariah. Masalah ini timbul ketika bank sebagai shahibu al-mal harus mengahadapi risiko ketika penyaluran dananya kepada masyarakat pada akad mudharabah di mana bank tidak diperkenankan turut campur dalam kegiatan sehari-hari usaha pengelola (mudharib).

Penjelasan yang paling banyak diketemukan adalah adanya moral hazard dipihak penerima dana yang sekaligus bertindak sebagai mudharib. Sementara itu disisi lain ketika bank bertindak sebagai mudharib, bank diwajibkan oleh ketentuan yang berlaku untuk bersifat transparan dan selalu diawasi oleh Bank Sentral. Pilihan mana yang akan diambil antara profit and loss sharing atau revenue sharing mempunyai konsekuensi yang berbeda.

Apabila profit and loss sharing yang dipilih, maka konsekuensinya jumlah yang harus dibagihasilkan telah dikurangi terlebih dahulu dengan semua biayabiaya yang diperlukan sehingga jumlahnya menjadi lebih sedikit. Sedang 
apabila revenue sharing yang dipilih maka konsekuensinya jumlah yang harus dibaghasilkan lebih banyak, tetapi bagi mudharib jumlah bagi hasil yang merupakan bagiannya itu menjadi berkurang karena semua ongkos-ongkos yang telah dipergunakan menjadi tanggungannya. Dengan demikian pada pilihan revenue sharing pihak yang selalu diuntungkan adalah shahibu al-mal., sedangkan pada profit and loss sharing dapat menguntungkan mudharib atau merugikan shahibu al-mal apabila biaya-biaya usaha tidak dikendalikan.

Dari pandangan syariah sebenarnya yang dikehendaki adalah profit and loss sharing (PLS) karena model inilah yang dicontohkan oleh Rasulullah SAW ketika beliau menjadi mudharib dari Siti Khadijah r.a. Namun dari segi praktis perbankan ada yang berpendapat bahwa sulit untuk mencari seorang mudharib yang kualitas pribadinya mendekati Rasulullah SAW. Jadi ada masalah moral hazard di pihak mudharib.

Dalam perspektif fikih yang harus dibagi-hasilkan adalah keuntungan bersih setelah dikurangi biaya-biaya (profit loss sharing) untuk kegiatan mudharabah dan tidak bolek keuntungan kotor sebelum dikurangi biaya-biaya. Sebab pembagian keuntungan tertentu yang terjadi pada akad mudharabah hanya boleh dilakukan setelah benar-bena jelas keuntungannya, setelah dikurangi biayabiaya. Hal ini adalah sesuai dengan pendapat para fuqaha dari madzhab Hanafi, Maliki dan sebagian Hambali berpendapat bahwa 'amil tidak berhak mendapatkan bagiannya dalam keuntungan kecuali setelah pembagian dan shahibu al-mal mendapatkan kembali modalnya secara utuh (Ibn Qudamah, th: 36).

Semua analisa akademikpun mengambil asumsi bahwa yang dilakukan lembaga keuangan syariah itu adalah profit and loss sharing karena secara nyata profit and loss sharing memang mempunyai dampak postif bagi pembangunan. Namun demikian fakta dilapangan pada sisi penyaluran dana kepada sektor usaha menunjukkan adanya berbagai macam usaha yang mempunyai karakteristik biaya yang berbeda. Bank sebagai pemilik modal (shahibu al-mal) tahap kedua menghadapi kesulitan untuk mengakui biaya-biaya usaha yang dikeluarkan para nasabah pengusaha sebagai mudharib. Padahal biaya biaya yang sulit diverifikasi inilah yang kemudian menjadi pengurang seluruh pendapatan yang akan dibagihasilkan.

Dalam bisnis yang biaya tidak terduga besarnya hal ini akan menjadi sumber perselisihan antara pemilik dana dengan mudharib tentang siapa yang 
harus menanggung biaya-biaya tersebut. Dalam proposal yang diajukan oleh mudharib biaya tersebut terlihat kecil sehingga pemilik dana mengharapkan keuntungan yang besar dari bisnis mudharib tersebut yang juga berarti bagi hasil yang besar bagi pemilik dana. Namun timbulnya biaya yang tak terduga yang sebelumnya tidak dikomunikasikan oleh mudharib kepada pemilik dana, tentunya akan mengakibatkan margin keuntungan yang kecil sehingga bagi hasilnya pun kecil. Dalam hal mudharib telah menyampaikan secara transparan, maka tanggung jawab sepenuhnya berada pada pemilik dana karena pemilik dana sedah mengetahui resiko bisnis (business risk) yang dihadapinya.

Namun dalam hal mudharib tidak menyampaikan secara transparan, maka untuk menghindari perselisihan mengenai siapa yang harus menaggung biaya tidak terduga itu, pemilik dana dapat menetapkan syarat bahwa biaya-biaya yang tidak terduga tersebut sepenuhnya menjadi tanggung jawab mudharib atau dengan kata lain yang dibagihasilkan adalah revenue.

Terkait dengan kesulitan bank sebagai pemilik modal (shahibu almal) tahap kedua atau pemegang amanah dari pemilik modal (shahibu al-mal) tahap pertama untuk mengakui biaya-biaya usaha yang diajukan mudharib, maka pada tahapan awal, telah disepakati pada rapat Dewan Syariah Nasional (DSN) dan Dewan Standar Akuntasi Keuangan Ikatan Akuntan Indonesia tanggal 10 Juni 2000 bahwa revenue sharing dapat dilakukan pada perbankan. Karena bank mempunyai dua peran ganda yaitu sebagai mudharib dan juga sebagai shahibu al-mal maka pada waktu bank bertindak sebagai mudharib, yang akan diuntungkan adalah shahibu al-mal yang dalam hal ini adalah para pemilik tabungan mudharabah dan deposito mudharabah, sedangkan pada giliran bank bertindak sebagai shahibu al-mal pada akad mudharabah, maka bank ada di pihak yang diuntungkan.

Dalam rangka pemurnian pelayanan perbankan syariah, telah direkomendasikan oleh peserta seminar "Problem of Islamic Banks" yang diselenggarakan bersama antara Islamic Research and Traning Institute (IRTI) IDB dengan Fiqh Academy (Lembaga Fatwa) dari Organisasi Konferensi Islam (OKI) bulan April 1993 di Jeddah, Saudi Arabia, bahwa perbankan syariah harus mengurangi ketergantungannya kepada pembiayaan berbasis mark-up, dan mengerahkan segala upaya untuk berpartisipasi dalam kegiatan pembiayaan dengan mempergunakan prinsip profit and loss sharing. Lalu bagaimana kita menanggapi seruan agar 
bank syariah di Indonesia juga dapat memulai pembiayaan penyertaan modal dengan prinsip profit and loss sharing tersebut?. Pembiayaan penyertaan modal di Indonesia masih menggunakan prinsip renenue sharing khususnya pada posisi bank sebagai mudharib pertama.

Bisa dibayangkan dengan tingginya biaya operasional perbankan syariah di Indonesia bagaimana kalau bank-bank syariah tersebut menganut profit and loss sharing? Tentu bagihasil yang dibagikan kepada nasabah penyimpan dana (tabungan mudharabah dan deposito mudharabah) akan lebih kecil dari bagi hasil yang telah dicapai sekarang. Apakah akan bisa bersaing dengan tingkat bunga simpanan perbankan konvensional? Dengan masih tingginya biaya operasional perbankan syariah di Indonesia, maka perlu dilakukan usaha bersama para pimpinan bank syariah untuk terus mengefisienkan diri dan di sini pentingnya diterapkannya secara utuh prinsip-prinsip ajaran Islam yang mengharuskan kita berperilaku efektif dan efisien dan meningkatkan pelayanan dengan baik.

\section{Penutup}

Dari pembahasan di atas kita dapat disimpulkan bahwa mudharabah adalah sesuatu yang sangat dianjurkan dalam Islam agar kita dapat saling membantu dalam menanggung resiko usaha tentu yang sesuai dengan syariah. Mudharabah termasuk salah satu jenis kerjasama, yang saat ini memiliki banyak kendala dalam perkembangannya sehingga shahibul mal/bank enggan memakai skema kontrak ini.

Sistem bagi hasil (mudharabah) merupakan landasan investasi dan karakteristik umum oprasional bank syariah dalam upanya menghindari praktek ribawai. Tingginya risiko (high risk) dari calon pengelola (mudharib) karena moral hazard dan kurangnya kesiapan sumberdaya manusia di perbankan syariah inilah di antara faktor yang menjadikan komposisi penyaluran dana kepada masyarakat lebih banyak dalam bentuk pembiayaan jual beli (murabahah) dibandingkan penyertaan modal (mudhrabah). Adanya batasn-batasan yang bisa dilakukan untuk mengoptimalkan pembiayaan mudharabah ini antara lain; keharusan adanya garansi (jaminan) atau anggunan berupa fixed asset dan menetapkan rasio maksimal bianya oprasional serta pembagian keuntungan berdasarkan profit and loss sharing. 
Untuk mengurangi kemungkinan terjadinya resiko-resiko kerugian bank syariah akibat kelalaian mudharib, bank syariah dapat menerapkan sejumlah batasan-batasan tertentu ketika menyalurkan pembiayaan kepada mudharib, di antaranya: 1) Penetapan agunan berupa fixed asset dan (atau) adanya lembaga penjamin; 2) Penetapan rasio maksimal biaya operasi terhadap pendapatan operasi; dan 3) Kembali kepada asas profit loss sharing pada akad penyertaan modal dan revenue sharing pada akad penghimpunan dana.

\section{DAFTAR PUSTAKA}

al-Baihaqi. tth. al-Sunān al-Kubra, Beirut: Dar al-Fikr.

al-Haytami, Abdurrazak Rahim Jiddi. 1998. al-mashārif al-Islamiyyah baina alNadzhariyah wa al-Tatbiq, Aman: Dar Usamah lin- Nasr.

al-Shan'ani. 1990. Subul al-Saläm, Dar al-Kutub al-Araby.

al-Zuhayli, Wahbah. 1997. al-Fiqh al-Islämi wa Adillatuh, Beirut:Dar al-Fikr.

al-Zuhayli, Wahbah. 1998. Nazhariyah al-Dhaman al-Ahkam al-Masuliyyah alMadaniyyyah wa al-Jinaiyyah al-Fiqh al-Islami, Suriya: Dar al-Fikr.

Antonio, Muhammad Syafi'i. 2009. Bank Islam Dari Teori ke Praktek, Jakarta: Gema Insani Press.

Bank Indonesia. 2012. Statistik Perbankan Syariah, Jakarta: Bank Indonesia.

Heri Sudarsono. 2007. Bank dan Lembaga Keuangan Syariah Deskripsi dan Ilustrasi. Yogyakarta:Ekonosia.

Ibn Qudamah. tth. al-Mughni, Beirut: Dar al-Kutub al-Ilmiyah.

Ibn Rusyd. tth. Bidayah al-Mujtahid, Beirut: Dar al-Fikr.

Karim, Adiwarman. 2003. Bank Islam Analisia Fikih dan Keuangan, Jakarta: IIIT.

Khallaf, Abdul Wahab. 1993. Kaidah-kaidah Hukum Islam, Jakarta:Rajawali Pers.

Muhammad. 2002. Manajemen Bank Syariah. Yogyakarta:UPP AMPYKPN.

Qal'aji, Muhammad Rawas. 1985. Mu'jam Lughat al-Fatawa, Beirut:Darun Nafs. Sabiq, Sayyid. 1995. Fikih Sunnah, Beirut: Daar al Fikri.

Saeed, Abdulah. 2006. Menyoal Bank Syariah, Jakarta: Paramadina. 
Saeed, Abdullah. 2003. Bank Islam Dan Bunga Bank, Studi Kritis dan Interpretasi Kontemporer tentang Riba dan Bunga, Yogyakarta: Pustaka Pelajar.

Syafe'i, Rachmat. 2004. Fikih Muamalah untuk IAIN, STAIN, PTAIS, dan Umum, Bandung: Pustaka Setia. 